\title{
DOES SERIOUS OFFENDING LEAD TO HOMICIDE? EXPLORING THE INTER-RELATIONSHIPS AND SEQUENCING OF SERIOUS CRIME
}

\section{Keith Soothill ${ }^{1}$, Brian Francis ${ }^{2}$ and Jiayi Liu ${ }^{3}$}

\footnotetext{
${ }^{1}$ Emeritus Professor of Social Research, Department of Applied Social Science,

${ }^{2}$ Professor of Social Statistics, ${ }^{3}$ Research Officer, Centre for Applied Statistics, Lancaster University, UK
}

Word count of manuscript $-7,393$ words (including references, footnotes, tables and figures).

Corresponding Author: Brian Francis

Address for correspondence:

Brian Francis,

Centre for Applied Statistics

Fylde College

Lancaster University,

Lancaster LA1 4YF

UK

Tel: +44 (0)1524 593061

Fax: +44 (0)1524 592681

E-mail: B.Francis@Lancaster.ac.uk

November 2007

Revised March 2008

Final version April 2008 


\title{
DOES SERIOUS OFFENDING LEAD TO HOMICIDE? EXPLORING THE INTER-RELATIONSHIPS AND SEQUENCING OF SERIOUS CRIME
}

\begin{abstract}
The inter-relationships between serious types of crime have been neglected. Focusing on those convicted of arson $(n=45,915)$, blackmail $(n=5,774)$, kidnapping $(n=7,291)$ and threats to kill $(n=9,816)$ in England and Wales (1979-2001), we examine the specialisation and sequencing of these crimes in relation to the risk of subsequent homicide.
\end{abstract}

All four offences have a heightened likelihood of subsequent homicide compared to the general population. Arson, blackmail and threats to kill have a similar homicide risk (0.8\%) after a 20-year follow-up; in contrast, kidnapping has a higher likelihood (1.0\%). Sequencing is also relevant, with those convicted of more than one type of serious offence being at higher risk of a homicide conviction.

Additionally, there is evidence of specialisation (particularly for arsonists) among serious offenders who recidivate.

\section{Keywords}

Arson, blackmail, kidnapping, threats to kill, homicide, reconviction 


\section{Introduction}

Much of the criminological focus in recent years has been on high frequency/low tariff offences where the versatility of most offenders' behaviour has been identified. With these offenders the case for specialisation has been limited although elsewhere (Soothill et al., 2000) we have argued that the conceptualisation of the issue needs further development. In contrast, there has been much less criminological focus on low frequency/high tariff offences. The exception over the past decade has been the increased interest in sexual offending. In relation to other high tariff serious crime, the focus is usually on one type of offence, such as arson (e.g. Soothill et al., 2004) and there is the apparent criminological neglect of many such crimes, such as blackmail or threats to kill. More pertinently, there seems to have been little discussion about possible comparisons and inter-relationships between different types of serious offences. Are those convicted of kidnapping more likely than those convicted of blackmail to go on to be reconvicted for homicide, for example? Similarly, are those convicted of, say, both arson and threats to kill more likely to go on to be convicted of homicide than those convicted of only one type of serious crime? The questions are important ones both for theoretical and practical reasons.

In thinking theoretically about serious offenders who recidivate one needs to ask how many types of offending domain they occupy. This question relates to the fraught issue of specialisation. Are kidnappers distinct from blackmailers? Are those convicted of threats to kill (a potentially serious offence against a person) totally distinct from those convicted of arson (a 
serious offence on property)? And so on. If they are distinct, this would perhaps suggest that one needs different types of theoretical explanations for different types of serious crimes. In contrast, if there is quite considerable overlap between those committing different types of serious offences - that is, those who are convicted of blackmail also tend to get convicted of kidnapping during their criminal careers, then there is perhaps more scope for a more general explanation, such as the low self-control approach espoused by Gottfredson and Hirschi (1990) who have espoused a general theory of crime.

This paper is a demonstration project probing the overlap between different kinds of serious offences. It is a demonstration rather than a definitive study simply in terms of probing whether a largely uncharted journey is worth undertaking.

Certainly the overlap issue may be important for explanation. However, the practical issue is a different but related one. If, for example, someone with a kidnapping and a blackmail conviction is more likely to kill subsequently rather than someone with a single blackmail conviction, then one can make a better appraisal of the type of risk that is at issue and the type of support or surveillance that may be needed.

\section{Previous literature}

There seems little work that considers the overlap between different types of serious crime. However, we have previously ventured into this area. For example, we found in a matched case-control study of precursors to 
murder that "a previous conviction for kidnapping was shown to be a statistically significant risk factor for murder, when compared against general criminal controls and against violent controls" (Soothill et al., 2002: 33). Similarly, for blackmail, "those with a blackmail conviction were over five times as likely to become murderers as the general controls" (Ibid. p.34].

More recently Liu et al. (in press) examined the time from the first conviction for kidnapping to some specific subsequent serious crimes: a subsequent kidnap, murder, manslaughter, and rape of a female. Using survival analysis procedures, this work estimated that 5 out of every 100 kidnap offenders convicted of kidnapping will be reconvicted for this offence. In contrast, one in every 100 kidnap offenders will be convicted of homicide after 20 years and close to 2 out of every 100 will be convicted of rape of a female in 20 years. It was further demonstrated that kidnappers are over 30 times more likely than males in the general population to be convicted of homicide and four times more likely than sex offenders.

Further, it seemed from our earlier research (Soothill et al., 2002) that those who were subsequently convicted of murder following a kidnapping conviction seemed to be much closer in time to the earlier kidnapping conviction compared, for instance, to those who were convicted of blackmail where the subsequent killing often seemed to be more distant in time.

In brief, this earlier work certainly suggests that those convicted of kidnapping or blackmail are at greater risk of being subsequently convicted of 
murder, but it falls short of comparing systematically various kinds of serious offences and probing the possible inter-relationships between them. In a hierarchy of potential dangerousness, how do offenders committing various kinds of serious offences measure up? Also to what extent is there an overlap between serious offences - in brief, do offenders who commit these types of offences specialise in certain types of offending or is their serious criminal behaviour much more versatile?

\section{Aims of the current paper}

This paper probes the issues of comparison and possible interrelationships by considering four specific types of serious crime - arson, blackmail, kidnapping and threats to kill. The choice of these offences was occasioned by three factors. Firstly, an earlier study identified that among general offenders with a previous criminal history these offences indicated an increased risk of murder (Soothill et al. 2002, especially Table 10). Secondly, these are seemingly very different types of serious offences and, finally, the availability of the data for these four offences. We refer to these four offences as "focus offences". Other offences could certainly claim attention but, as indicated earlier, this is a demonstration rather than a definitive study.

Certainly these four chosen offences do seem very different. While there will be variants, 'kidnapping' seems essentially a 'hands-on' potentially violent offence with face-to-face interaction, 'blackmail' seems a more 'handsoff' offence with little or no face-to-face interaction, 'threats to kill' seems a more verbal or written type of aggression which may or may not involve face- 
to-face interaction, and 'arson' is a serious property which may or may not endanger human life.

The choice of considering the likelihood of subsequent homicide provided continuity with our earlier work (Soothill et al. 2002). However, the choice of homicide (murder or manslaughter) rather than any other offences was also for reasons of both parsimony and pragmatism. There are, of course, other social harms, such as rape, which are potentially relevant, but the very low conviction rate for this offence, to take this example, may lead to a serious underestimate of this particular danger. By focusing on just one subsequent serious offence (namely, homicide) beyond the four serious offences already under consideration, we hope this will aid the clarity of the presentation. Pragmatically, in considering potential dangerousness, the relevance of a future homicide seems unquestionable.

\section{The questions}

The two main questions posed are straightforward ones:

1) For each of the four serious offences under consideration - the focus offences - what proportions go on to be reconvicted for the same offence, or get reconvicted for one of the other three serious offences, or for homicide (murder or manslaughter). Essentially this question is focusing on offence specialisation within each offence, and within the four focus offences . It is also concerned with escalation - how many escalate their activity to homicide, We will investigate this in two ways - firstly, by an uncontrolled descriptive analysis, which does not take into account the different follow-up times of our cohorts of serious offenders and, secondly, controlling for follow-up time and 
for time at risk. The latter analysis allows us to examine the speed of reconviction for the most serious type of reconviction, namely homicide.

2) For all cases in the dataset, are certain combinations and sequences of focus convictions risk factors for subsequent homicide? Again, we investigate this in two ways - firstly by means of a descriptive tabular analysis which does not control for differential follow up and time at risk, and then through a survival analysis which controls for these factors.

\section{Datasets and methods}

The study of serious offences is often doomed by the numerical lack of cases. However, this study does not suffer from this problem. We used the Offenders Index, which is an administrative dataset which consists of records of convictions for all standard list offences for all offenders in England and Wales since 1963. Extracts from the dataset are available for research purposes.

The datasets were constructed in two stages. First, we consider all those offenders convicted between 1979 and 2001 in England and Wales of arson, blackmail, kidnapping or threats to kill. Four separate datasets were constructed by following two restrictions. First of all, we wished to ensure that our offenders were convicted of their first focus offence (one of the four types above) between 1979 and 2001. Thus, those offenders who were convicted of any of the serious crimes of arson, blackmail or threats to kill, or of homicide between 1963 and 1978 (inclusive) ${ }^{1}$ were discarded. For example, a person who had been convicted of arson for the first time in 1977, and then convicted 
of blackmail in 1980 would be removed from both the arson dataset and the blackmail dataset ${ }^{2}$.

For each of the four datasets, we then defined the target conviction for an offender to be the first conviction of the offence of interest; thus the target conviction for an individual in the blackmail dataset would be the first blackmail conviction.

A second restriction was then applied. All those known to have been convicted of homicide prior to or as a co-conviction to the target conviction were eliminated from the relevant data set. The reason for that is we were interested in first -time subsequent homicide following a particular serious offence .

The resulting four datasets were arson $(n=45,915)$, blackmail ( $n=5,774)$, kidnapping $(n=7,291)$ and threats to kill $(n=9,816)$. As they were separate datasets, a person could be part of more than one dataset. In fact, there is overlap between the datasets; of the 67,052 persons in the four datasets (eliminating overlaps), 1,702 persons (or 2.5\%) were in two or more datasets.

Each dataset is sizeable, but the limitation of each dataset, however, is the paucity of the information on these offenders beyond their criminal history. The OI database, first started in 1963, provides information on gender, age at conviction and previous criminal history (that is, back to 1963). However, 
there is little or no detail on the nature of the crime, for instance. An exception is with arson where we can distinguish between offences that were considered to endanger life and those that were not.

The second stage was to combine the four datasets into a single dataset. This resulted in a dataset of 67,052 offenders in total. In this dataset, we define the target conviction to be the first conviction of any of the four serious focus crimes. The construction of this dataset allowed us to examine temporal sequences of serious crime convictions and the subsequent risk of first time homicide following these sequences.

This study is primarily concerned with reconviction. With this data, there are two methodological problems to confront. The first relates to followup time - those offenders having their first focus conviction in 2000 have only a limited follow up compared to those having a first focus conviction in 1979. The second problem relates to time spent in custody. Serious offenders are likely to spend part of their follow-up time in custody, and this is time then they are not at risk (or more exactly, at substantially reduced risk) of committing a further serious offence.

We have therefore carried out two analyses for each of the stages described above. We start the analysis of each stage by carrying out a straightforward descriptive analysis, examining the numbers of reconvictions of various offences without adjusting for follow-up time and time at risk. We then use survival analysis techniques to adjust for follow-up time and for time 
spent in custody. For the individual datasets at the first stage, we examine Kaplan-Meier survival curves; for the combined dataset (where we wish to examine risk factors) we carry out a Cox proportional hazards analysis,

Adjustment for time spent in custody is not straightforward, for while we have a record of sentence awarded including the length of any custodial sentence there is no indication of the actual time served since conviction on the Ol data. Again certain assumptions must be made. For the target conviction and for every conviction after that date which had a custodial sentence, we make an estimate of the custodial time served from the sentence length. We then adjust the time at risk by the sum of these times spent in custody. There are various unpredictable circumstances that can change the imprisonment time, such as whether the offenders will get remission or not, whether they get parole, and whether it is at the first, second or later opportunity. We estimate the time served as some fraction of the sentence length, taking the fraction to be $0.3^{3}$ in this paper.

By making this estimate for time at risk, there will be some individuals who are convicted of a homicide while our estimate says that they will still be serving time in custody. We deem these convictions pseudo-reconvictions. They are assumed not to be true reconvictions, but will relate to offences committed before the appropriate conviction, but discovered or admitted to later when the offender is in custody. 


\section{Results}

Using the four separate datasets constructed as the first stage, Table 1 shows the subsequent reconvictions for the four offences of arson, blackmail, kidnapping and threats to kill in terms of whether they were subsequently convicted for any of these focus offences, or of homicide. This preliminary analysis provides both clues and concerns. The concerns are the methodological ones that length of follow-up and time at risk have not been systematically taken into account. Nevertheless, using the four separate datasets with what was expected as an average follow-up period of around ten years, Table 1 presents some clues for a judge who is sentencing a person who has not been previously convicted of the particular offence of interest.

(Table 1 around here)

Our questions which relate to proportions, specialisation and the likelihood of a homicide reconviction have some preliminary answers:

1. Proportions. For each of the four separate offences (or datasets), an important minority go on to be convicted of at least one or more of the five serious offences of interest. The cumulative numbers of persons convicted for at least one of the four focus offences, shown as the penultimate column in Table 1 , range from $9.57 \%$ for those convicted of arson for the first time to $5.46 \%$ of those convicted of kidnapping for the first time. 
2. Specialised serious offending. The shaded diagonal in Table 1 shows the numbers and proportions who are reconvicted of the same type of offence as their original target conviction. Table 1 demonstrates that, within the four focus offences, the offenders tend to specialise in the type of subsequent offence they commit, by being more likely to be reconvicted of the same offence than one of the other three focus offences. Arsonists seem the most specialised with around 1 in 12 of those convicted of arson being later reconvicted for arson again. For the other three offences (blackmail, kidnapping and threats to kill), around 1 in 25 are reconvicted for the same offence again.

3. Subsequent homicide. Homicide can be regarded as the most serious reconviction and the four focus offences - arson, blackmail, kidnapping and threats to kill - have quite remarkably the same proportion (approaching $0.6 \%$ ) - that is, just over 1 in 200 - who are reconvicted for homicide. However, the figures are uncontrolled and there is no focus on the speed of reconviction for homicide.

While a useful guide, Table 1 has some limitations. The final column in Table 1 shows that the average follow-up time (in years) varies quite markedly for the four offences. Arson and blackmail offenders have the longest followup on average of around 12 years - this is because there has been a fall in the numbers convicted of these offences over the follow-up period. In contrast, threats to kill and kidnapping (with average follow-ups of 9 and 8 years respectively) have much lower follow-up periods; again the explanation relates to changes in the number of convictions over the follow-up period - for 
these two offences the number of convictions have risen over the follow-up period. This feature is demonstrated in Figure 1 which shows the first-time convictions for the four offences during the period under investigation.

(Figure 1 around here)

The other limitation of Table 1 as discussed above is that there is no control for periods genuinely at risk.

Following Liu et al. (in press) the differential follow-up periods can be dealt with by using a survival analysis technique. Using time at risk rather than calendar time, we estimate a Kaplan-Meier survival curve for each of our four offences, which gives an estimate of the proportion of offenders not reconvicted of homicide at any time $t$ after reconviction. Offenders contribute to the analysis from when they are convicted of their target offence up to when they get a homicide reconviction or until the end of the study in 2001 , whichever is earlier. Nevertheless, there are still certain assumptions that need to be recognised. Most importantly, the procedure assumes that those convicted in the early years (thus with long follow-up periods) will have similar characteristics to those convicted in the later years (with shorter follow-up periods). However, this assumption of no social change seems reasonable in these datasets.

Figure 2 shows the estimated homicide reconviction survival curves for the four focus offences. It usefully demonstrates that the different offences 
have different trajectories. At the twenty-year point, arson, blackmail and threats to kill all eventually reach very similar estimated proportions, that is, around $0.8 \%$. Kidnapping shows a different trajectory with an estimated rate of homicide reconviction at $1 \%$ (roughly, one in a 100) in a 20-year period at risk. Kidnapping, moreover, has a more rapid gradient and there were no more homicides in the second half of the follow-up. The gradients are also meaningful for the other offences with arson having a constant slope throughout the follow-up, while threats to kill and blackmail have intermediate trajectories with no further homicides after 12 and 15 years respectively. In other words, the gradients provide some clues as to whether the risk of homicide remains constant, falls or rises over periods of time. This feature has relevance for the length of supervision which may be required for different offences.

(Figure 2 around here)

However, despite using the survival analysis technique and controlling for actual time at risk, there is still a concern about comparing the four datasets. After all, there are 1,702 persons who are in two or more of the datasets. Perhaps these persons contribute disproportionately to the homicide reconviction rate and may be the reason why the reconviction rates for homicide look so similar for the four offences.

At stage two, we now consider the combined dataset of 67,052 persons for whom the offence of arson, blackmail, kidnapping or threats to kill 
first occurred in 1979 or after. Table 2 presents the outcome in terms of subsequent homicide and reveals that the overall homicide rate is $0.52 \%$ (roughly 1 in 200). However, the important feature of Table 2 is that it shows the effect of (1) being convicted of one of these focus offences on two or more occasions (but without being convicted of one of the other serious offences) and of (2) being convicted of two or more different kinds of serious focus offences.

(Table 2 around here)

First, considering those who were convicted of one of these serious offences on two or more occasions, the pattern is different for arson compared to the other three offences. With arson, the chances of being convicted of homicide almost doubles when the person has two or more two occasions with an arson conviction (from $0.48 \%$ after being convicted for arson on just one occasion to $0.84 \%$ after being convicted for arson on more than one occasion). With the other three offences, the proportions subsequently convicted for homicide actually declines - albeit only marginally for kidnapping - when a person is convicted of one of these offences on two or more occasions. This seems to be counter-intuitive but one can perhaps recognise that it is conceivable that more threats to kill are evidence of a lower likelihood of subsequent homicide - as we suggest elsewhere (Soothill et al., 2007), perhaps dogs that continue to bark don't bite. However, also of course, by the time that a person has been convicted of a second serious offence, the length of the follow-up will on average be much shorter. This 
feature is shown in the last column of Table 2. For each offence, those with two or more convictions have on average a shorter follow-up period than those with just one relevant conviction.

Now moving on to the offenders who have been convicted between 1979 and 2001 of two or more of the four focus offences being considered. For almost every combination shown in Table 2 there is at least a doubling of the likelihood of being subsequently convicted of homicide compared with the figures when the offender has been convicted of just one of these serious offences. The exception is the combination of 'threats to kill and blackmail' where none of the 103 individuals convicted of this combination was subsequently convicted of homicide. This outcome supports the earlier finding that, for both threats to kill and blackmail, the likelihood of a subsequent homicide declines if offenders are convicted more than once for these offences.

There seems to be a further curious twist to Table 2. None of the persons who were convicted of three or four of these serious offences was reconvicted for homicide. However, the numbers are small - a total of 53 persons - and the average follow-up period for each of these combinations is, not surprisingly, comparatively short.

Table 2 has focused on the various combinations of serious convictions during the period 1979 and 2001. A feature which Table 2 currently masks is the sequencing of the serious offences when more than one kind of serious 
offence is involved. Table 3 attempts to do this. Where a serious offence occurs at one court appearance and another serious offence is convicted on another occasion, the two events are separated by a slash line (e.g. A/T); where the two serious offences are convicted on the same occasion, then there is no such separation.

(Table 3 around here)

The number of homicides are comparatively few in each combination so the problem of chance fluctuations is heightened. Mostly there are no subsequent homicides. Nevertheless, tentatively one could point to two possible patterns which can be identified. Firstly, for arson \& threat, arson \& blackmail and arson \& kidnapping, there seems to be more danger of a reconviction if the two offences are convicted on separate occasions - lin other words, when they are co-convictions, there is no evidence of any subsequent homicides. In contrast, for threat \& kidnapping and blackmail \& kidnapping, there is no such relationship - indeed, co-convictions for threats \& kidnapping seem to be a particular concern, and so endorsing the worry about the behaviour of kidnappers after release (see Liu et al. in press). Finally, as mentioned earlier, the combination of threat \& blackmail does not produce any subsequent homicides.

With three or more serious offences involved, the combinations are various but, as already noted, the remarkable feature is that there are no subsequent convictions for homicide recorded among this motley group. 


\section{Probing risk factors for homicide}

Tables 2 and 3 have described the observed rate of subsequent conviction of homicide following various combinations of arson, threats to kill, blackmail, and kidnapping. It suggested that those offenders who were specialised in their serious crime behaviour, involving only one type of crime of interest, have a lower risk of being subsequently convicted of homicide than those who involving two or more types of serious crime. However, in this essentially descriptive analysis, there was no attempt to control for follow-up time or time at risk.

We now need to proceed more formally in controlling for these effects, and in doing so, to assess the evidence of difference in risk of subsequent homicide convictions between those offenders who were convicted of only one of our focus offences and whose who had mixed types of convictions. We also wish to explore if any types of sequencing are related to a higher risk of subsequent homicide conviction. We use the Cox proportional hazards model to look for risk factors for a subsequent homicide conviction following one or more serious crimes of interest.

By doing so, we will also be able to control for other important risk factors such as gender, age at conviction, and previous convictions; it is recognised that these three risk factors are important in the prediction of recidivism. 
The sequencing of the serious focus crimes starts with the first focus conviction, and ending with the last focus conviction prior to homicide. We take the last of these convictions and examine time from that conviction to homicide, adjusting for periods spent in custody as described earlier in the paper.

To summarize the sequencing of an offender's serious criminal history we take five measures which will be potential risk factors in the Cox analysis.

a) The type of the first focus conviction in the sequence (i.e. arson, blackmail, kidnapping, threats to kill or a mix of more than one of these offences).

b) The type of the last conviction in the sequence.

c) The number of different types of focus offences involved in the sequence. This measures the diversity of serious offending.

d) The number of focus offences, giving a measure of serious offence frequency.

e) The length of the sequence; that is, the time between the first and last focus offence in the sequence.

We have also used gender of offender, number of previous convictions and age at the last focus conviction as general criminological risk factors. We logged the number of previous convictions as previous work has shown that this is a better predictor than the unlogged covariate. 
We fitted a series of Cox proportional hazard models, selecting a final model by examining the AIC (Lindsey and Jones, 1998) for each model, removing insignificant risk factors. The final model with the lowest AIC included age, gender, logged previous convictions, the type of the first serious offence, and the number of different types of serious offence. All other potential risk factors were not significant.

The Cox analysis models the underlying hazard rate (rather than survival time), and the results are shown in Table 4. As we expected, males are more at risk of a homicide conviction than females $(p<0.042)$, with the risk doubling compared to females. Also as expected, the risk of homicide declines with age $(p<0.001)$, with around a 5\% decline in risk for each year of age and increases with the number of prior convictions $(p<0.001)$.

(Table 4 around here)

Turning our attention to the risk factors summarising the sequencing of the four focus offences, we found that two of our five measures were important. Firstly, the type of the first serious offence is a significant risk factor for subsequent homicide. An offender who began their serious offending with kidnapping has about $48 \%$ higher risk of homicide compared with one who started with arson; similarly an offender who began with threats to kill has around 55\% higher risk over the arson offender. Other types of starting offence shows no significant difference from arson. This is consistent with the results shown in Table 3. Offenders who start their criminal career with 
kidnapping then followed by arson (K/A) had a high rate of subsequent homicides (5.41\%). Similarly, the offence of threats to kill followed by arson has a similarly high homicide rate (3.45\%).

Secondly, the number of distinct types of serious offences was also a significant risk factor, with increasing homicide risk as the number of types increases. Thus, the offender who had two types of serious offence has nearly double (1.82) the risk of subsequent homicide conviction compared with an offender with only a single type of serious offence. This is also consistent with Table 2.

The specialist/generalist debate among serious offenders

Earlier we suggested that has been little consideration of the specialist/generalist debate in relation to serious offences. In brief, do offenders who continue with serious crime specialise in certain types of serious offending or is their criminal behaviour more versatile? Our view of specialisation in this study is somewhat different to other specialisation studies- here we are concerned solely about "serious offence" specialisation within the four focus offences. Thus, someone with two arson convictions but no convictions for blackmail, threats to kill or kidnap would be deemed a specialist whether or not they had additional convictions for theft, criminal damage etc.

Table 5 shows that, during the full observation period, the vast majority of the total series are convicted of just one of the four focus offences under 
consideration. However, now considering all the persons who have been convicted on at least two occasions of one or more of these serious offences produces some further clues in relation to the specialist/generalist debate.

(Table 5 around here)

Table 5 shows that there is a range on the specialist/generalist continuum. Those convicted of arson are the most likely to specialise - they are four times more likely to be only convicted of arson subsequently than being convicted of one of the other serious offences being considered (3664 persons compared to 866 in Table 5). In contrast, the other three offences are in the opposite direction. Those first convicted of kidnapping are over four times more likely to be considered as a generalist than a specialist (979 are not specialised, while only 216 are). Similarly, those convicted of blackmail or threats to kill are around two and a half times more likely to be considered to be generalists rather than specialists. These findings have important implications for considering serious offending.

\section{Discussion and Conclusions}

This article has been an attempt to open up a discussion about the inter-relationships between serious types of crime, for we maintain that this feature of criminal careers has been neglected in the criminological literature. The results should, hopefully, encourage more to think about this topic. 
However, a further analysis is perhaps unlikely to challenge the following points:

- There is evidence that those convicted of one of the four focus offences often specialise in the types of serious offences for which they get convicted. . However, they vary in this respect with those convicted of arson the most likely to specialise. Evidence of specialisation is contrary to low-tariff high-volume offenders.

- Those convicted of arson, blackmail, and threats to kill all have very similar proportions in terms of subsequent convictions for homicide $(0.8 \%)$ in a 20 -year period at risk - that is, around 1 in 160 . However, kidnapping offenders seem to be more dangerous in this respect with a higher proportion (1.0\%) - around 1 in 100 - being subsequently convicted of homicide. This compares with the likelihood of around 1 in 3,000 male members of the general population being convicted for homicide over a 20-year follow-up period (Francis and Soothill, 2000).

- The speed of reconviction for homicide varies for these four offences. In particular, kidnapping shows the most rapid gradient with a heightened risk of homicide in the early years after conviction. In contrast, arson offenders have a fairly constant rate over the 20-year period.

- The effect of having two or more convictions for one or more of the four offences is complex. However, the effect becomes clearer when incorporated into a statistical analysis of risk factors for homicide. In brief, while sequencing is interesting, the nature of the first serious 
offence and the number of the distinct types of serious offences are the two significant risk factors (as well as age, gender and the number of previous convictions).

The results are clear but what of the theoretical implications? In truth, the material in this paper tells nothing of the underlying motivations of the perpetrators and we can make no compelling case for any particular theoretical approach. However, there are still some signposts that are evident. First, though, one needs some caveats and warning notices. While approaching nine out of ten persons in the study were only convicted once for one of these serious offences, there could be convictions for other serious offences we have not considered; also this group could range from those being convicted of just this one offence to those whose serious offence resides among a vast range of lesser crime. Nevertheless, we can say with some confidence that nine of out ten are neither candidates for specialisation in the narrow sense ${ }^{4}$ nor for overlap in terms of the four offences. Whatever explanation one might have for the remaining ten per cent or so, the majority convicted of just one focus offence seem different in their involvement in serious crime in terms of it seemingly being much more transient.

The remaining ten per cent also have their differences beyond that of committing different kinds of offences. We have divided the total series into those we have termed as 'specialist' and those we have termed as 'not specialised'. Again, each of these two sub-groups can be involved in other types of crime (or not). Nevertheless, we feel we can make some 
observations relating to the specialist/generalist debate and to the issue of sequencing/switching As Piquero et al. (2003: 457) note, these two issues are directly related..

The specialist/generalist debate has been plagued by the notion that this needs to be a simple dichotomy, while we have argued that the interpretation is more complex and relates to the level of analysis being undertaken. In brief, an offender can be both a specialist and a generalist (Soothill et al., 2000). So, an offender can display a vast range of offending behaviour but, when he is involved in sexual offending, he may only engage, for example, in supposedly consensual sex with a girl under 16 years - the former vast range of offending behaviour may classify him as a generalist while the latter as a specialist within the realm of sexual offending. Something similar may be happening in this analysis.

When arson is the first serious offence, then arson is four times more likely to be the second serious offence rather than one of the other three offences considered in this study. For the other three offences, there is not the same relationship. Indeed, for these offenders it is more than twice as likely to be one of the other three offences. In short, even though we are not investigating the full repertoire of offending for each offender in this study, it still seems valid to speak of arson recidivists are being more likely to be specialised at a serious crime level than the members of the other three groups. 
We have also probed sequencing or switching. Apart from specialisation, the criminal justice system is also interested in whether offenders are likely to desist and, if not, whether they are likely to switch their offending focus. Elsewhere we made a modest attempt to consider offending pathways in terms of showing what offenders are doing in one five-year period compared to the following five-year period (Francis et al., 2004). However, as Armstrong and Britt (2004: 843) stress, "Virtually all research on patterns of offense types across the criminal career has focused on establishing whether offenders tend to commit the same or more serious types of offenses over time." Indeed, Armstrong and Britt's own work continues this tradition by focusing on specialisation and escalation. Hence, the focus on switching or sequencing has been somewhat limited. There seems, for example, to have been little interest in whether offenders switch from one serious offence to another. In this article we use the term 'sequencing' rather than 'switching' as the former term seems to imply that a particular behaviour may still continue although the criminal repertoire may increase, while the latter term seems to imply a more complete change of focus. The present analysis suggests that a study of sequencing has some merit. So, for example, being convicted of arson and threats to kill on different occasions seems to present a greater danger of subsequent homicide than being convicted of these two offences on the same occasion. Nevertheless, it is also useful to remind that another interpretation is quite simply that two separate court appearances are a greater danger than one court appearance. However, this, in turn, can be countered from the evidence in this study that threats to kill followed by an arson conviction on another occasion seem to be a harbinger of greater 
danger than the convictions for these two offences occurring in the reverse order. In brief, the value of sequencing is not really proven in this study, but we can endorse that there should be more interest in the topic.

While reiterating the usual need for more research, we suggest that our study does provide a methodology and some results which chart the way forward for considering serious offences. In probing the risk for homicide (which is, after all, a rigorous measure of future danger), it is clear that the type of the first serious offence and the number of distinct types of serious offences are both serious risk factors for subsequent homicide. This supports our wider belief that in studying and understanding criminal careers both the quality and the quantity of the offending is relevant.

\section{Acknowledgments}

Earlier versions of this paper were presented at the International Symposium on Forensic Sciences, February 2006, at the Amity University, Uttar Pradesh, India. and at the American Society of Criminology conference in Los Angeles in November 2006. This work was partially funded under the ESRC National Centre for Research Methods Lancaster-Warwick node - grant number RES-576-25-5020.

\section{References}

Armstrong, T. A. and Britt, C. L. (2004) 'The effect of offender characteristics on offence specialization and escalation', Justice Quarterly, 21(4), 843876. 
Francis, B. and Soothill, K. (2000) 'Does sex offending lead to homicide?' Journal of Forensic Psychology, 11 (1), 49-61.

Francis, B., Soothill, K., and Fligelstone, R. (2004) 'Identifying patterns of offending behaviour: A new approach to typologies of crime', European Journal of Criminology, 1(1), 47-87.

Gottfredson, M R and Hirschi, T (1990) A General Theory of Crime. Stanford, California: Stanford University Press.

Home Office (1996). Prison Statistics England and Wales 1995. London: HMSO.

Lindsey, J. K. \& Jones, B. (1998) Choosing among generalized linear models applied to medical data. Statistics in Medicine, 17, 59-68.

Liu, J., Francis, B. and Soothill, K. (In press) Kidnapping offenders: Their risk of escalation to repeat offending and other serious crime. The Journal of Forensic Psychiatry and Psychology.

Piquero, A. R., Farrington, D. P. and Blumstein, A. (2003) 'The criminal career paradigm', Crime and Justice: A Review of Research, 30, 359-506.

Soothill, K., Francis, B., Sanderson, B. and Ackerley, E. (2000) 'Sex Offenders: Specialists, Generalists - or Both?' British Journal of Criminology, 40, 56-67.

Soothill, K., Francis, B., Ackerley, E. and Fligelstone, R.. (2002) Murder and serious sexual assault: What criminal histories can reveal about future serious offending. London: Home Office.

Soothill K, Ackerley E and Francis B (2004) The criminal careers of arsonists. Medicine, Science and the Law. 44 (1): 27-40 
Soothill, K., Francis, B. and Ackerley, E. (2007) 'Do dogs that bark also bite? Threats to kill: a criminal profile of persons convicted 1963-2001'. Paper presented at the American Society of Criminology conference in Atlanta, November 2007. 
Figure 1: Number of first-time convictions for four serious crimes.

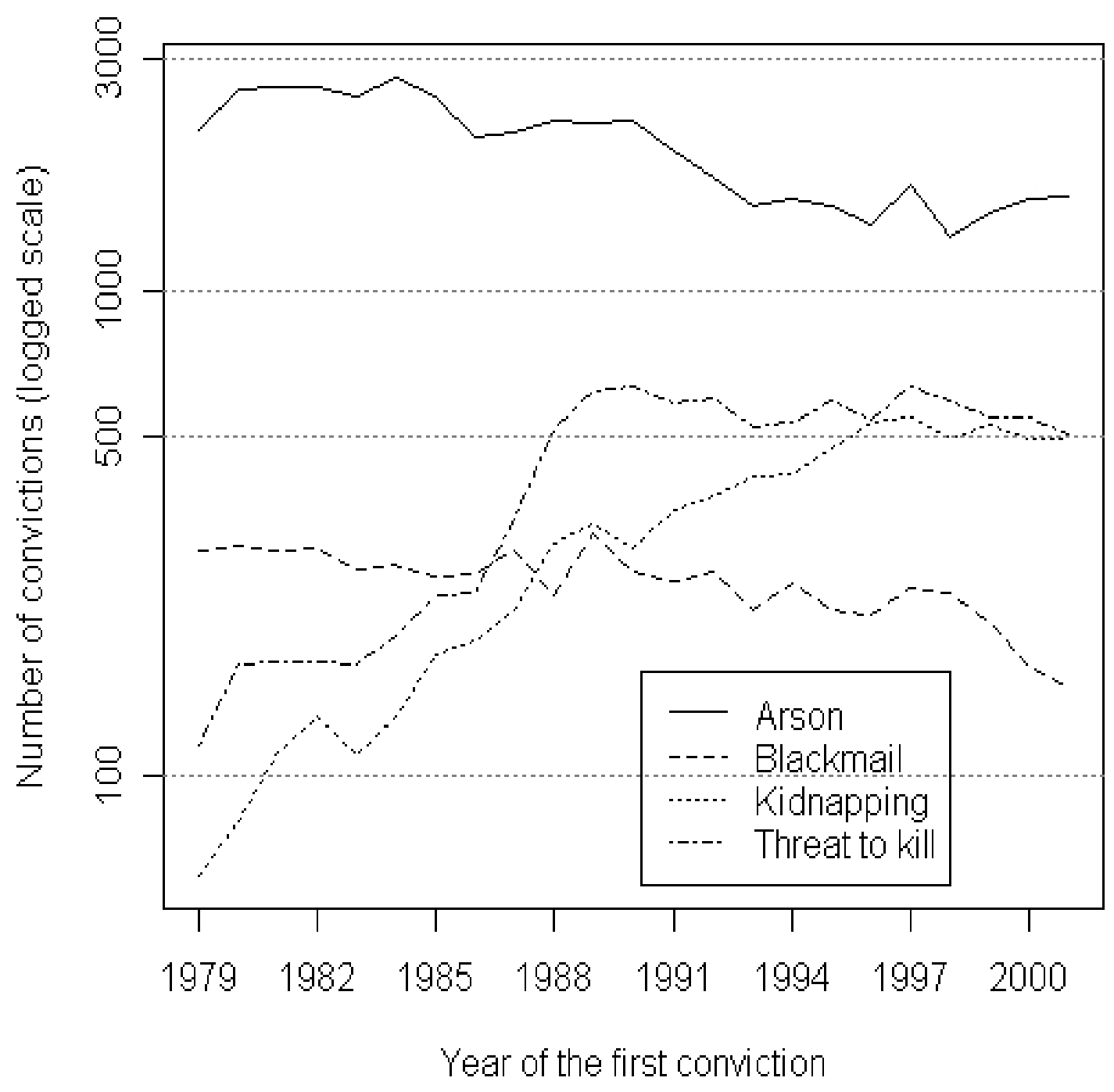


Figure 2: Survival curves for risk of homicide (adjusted for time at risk) following four serious crimes.

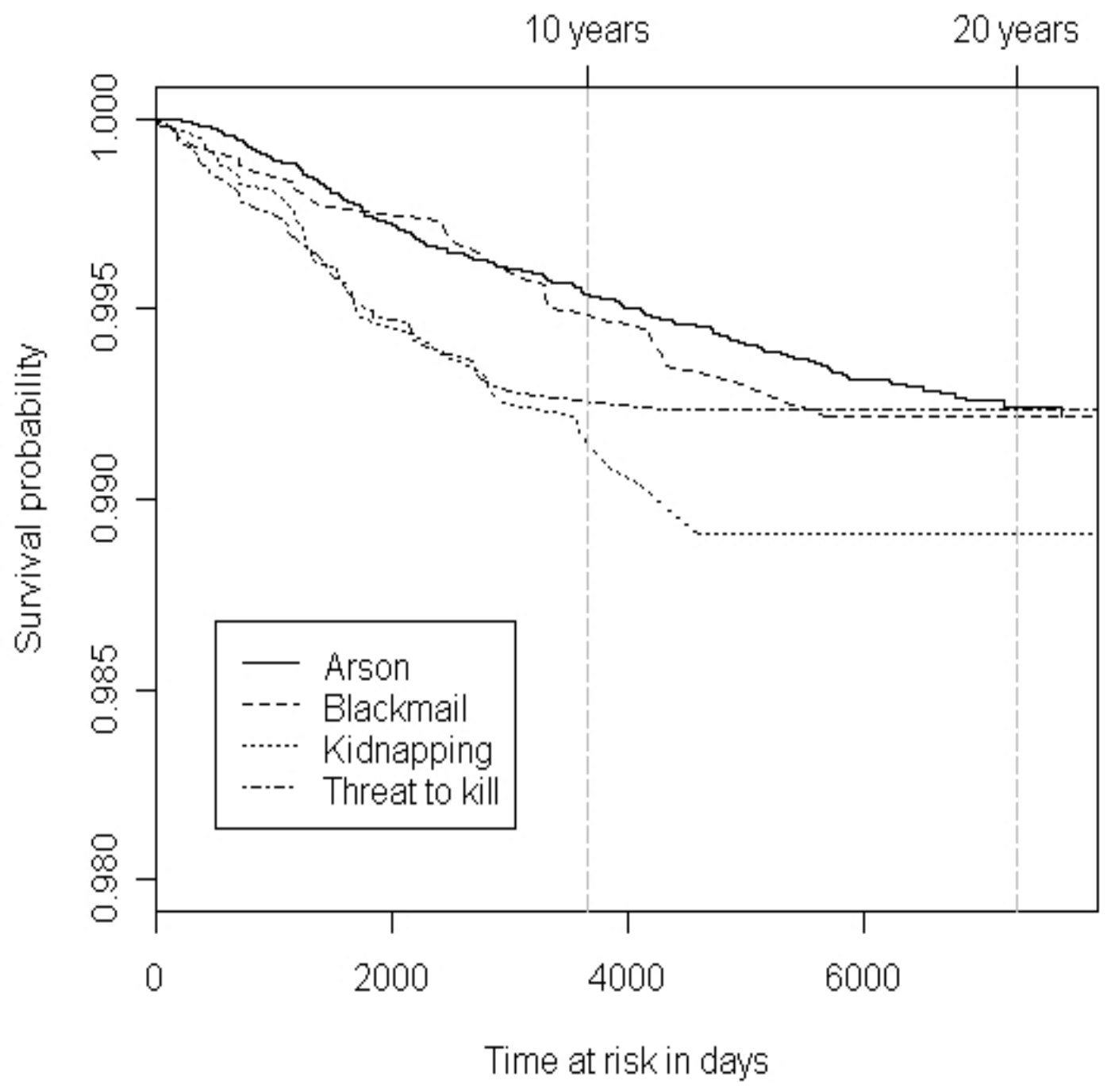


Table 1: The number of offenders with subsequent convictions for serious offences following the target (first time) conviction.

\begin{tabular}{|c|c|c|c|c|c|c|c|c|}
\hline & $\begin{array}{c}\text { No. of } \\
\text { persons }\end{array}$ & $\begin{array}{c}\text { No. } \\
(\%) \\
\text { ARSON }\end{array}$ & $\begin{array}{c}\text { No. } \\
(\%) \\
\text { BLACKMAIL }\end{array}$ & $\begin{array}{l}\text { No. } \\
\text { (\%) } \\
\text { KIDNAP }\end{array}$ & $\begin{array}{c}\text { No. } \\
(\%) \\
\text { THREATS } \\
\text { TO KILL }\end{array}$ & $\begin{array}{c}\text { No. } \\
(\%) \\
\text { HOMICIDE }\end{array}$ & $\begin{array}{c}\text { No. } \\
(\%) \\
\text { COMBINED } \\
\text { TOTAL* }^{*}\end{array}$ & $\begin{array}{l}\text { Average } \\
\text { follow-up } \\
\text { time in } \\
\text { years } \\
\text { (SD) }\end{array}$ \\
\hline ARSON & $\begin{array}{r}45,915 \\
(100)\end{array}$ & $\begin{array}{l}3,819 \\
(8.32)\end{array}$ & $\begin{array}{r}79 \\
(0.17)\end{array}$ & $\begin{array}{r}160 \\
(0.35)\end{array}$ & $\begin{array}{r}280 \\
(0.61)\end{array}$ & $\begin{array}{r}239 \\
(0.52)\end{array}$ & $\begin{array}{r}4394 \\
(9.57)\end{array}$ & $\begin{array}{l}12.89 \\
(6.49)\end{array}$ \\
\hline BLACKMAIL & $\begin{array}{r}5,774 \\
(100)\end{array}$ & $\begin{array}{r}52 \\
(0.90)\end{array}$ & $\begin{array}{r}279 \\
(4.83)\end{array}$ & $\begin{array}{r}65 \\
(1.13)\end{array}$ & $\begin{array}{r}51 \\
(0.88)\end{array}$ & $\begin{array}{r}32 \\
(0.55)\end{array}$ & $\begin{array}{r}438 \\
(7.59)\end{array}$ & $\begin{array}{l}12.40 \\
(6.46)\end{array}$ \\
\hline KIDNAPPING & $\begin{array}{l}7,291 \\
(100)\end{array}$ & $\begin{array}{r}44 \\
(0.60)\end{array}$ & $\begin{array}{r}21 \\
(0.29)\end{array}$ & $\begin{array}{r}273 \\
(3.74) \\
\end{array}$ & $\begin{array}{r}61 \\
(0.84)\end{array}$ & $\begin{array}{r}44 \\
(0.60)\end{array}$ & $\begin{array}{r}398 \\
(5.46) \\
\end{array}$ & $\begin{array}{r}8.18 \\
(5.61)\end{array}$ \\
\hline $\begin{array}{l}\text { THREATS } \\
\text { TO KILL }\end{array}$ & $\begin{array}{l}9,816 \\
(100)\end{array}$ & $\begin{array}{r}110 \\
(1.12)\end{array}$ & $\begin{array}{r}27 \\
(0.28)\end{array}$ & $\begin{array}{r}63 \\
(0.64)\end{array}$ & $\begin{array}{r}473 \\
(4.82)\end{array}$ & $\begin{array}{r}56 \\
(0.57)\end{array}$ & $\begin{array}{r}682 \\
(6.95)\end{array}$ & $\begin{array}{r}9.07 \\
(5.62)\end{array}$ \\
\hline
\end{tabular}

*'COMBINED TOTAL' refers to the total number of persons convicted subsequently of at least one of the five offences (arson, blackmail, kidnapping, threats to kill, or homicide). 
Table 2: Percentage of serious offenders of various types who are subsequently convicted of homicide from 1979 to 2001 in England and Wales.

\begin{tabular}{|c|c|c|c|c|}
\hline Type of dataset & $\begin{array}{l}\text { No. of } \\
\text { offenders }\end{array}$ & $\begin{array}{c}\text { No. of } \\
\text { subsequent } \\
\text { homicides }\end{array}$ & $\%$ & $\begin{array}{l}\text { Average follow- } \\
\text { up time in years } \\
\text { (SD) }\end{array}$ \\
\hline Arson(1) & 41,385 & 198 & 0.48 & $\begin{array}{l}12.82 \\
(6.52) \\
\end{array}$ \\
\hline $\operatorname{Arson}(2+)$ & 3,664 & 31 & 0.84 & $\begin{array}{l}11.19 \\
(6.08)\end{array}$ \\
\hline Threats to kill(1) & 8,439 & 46 & 0.52 & $\begin{array}{r}9.09 \\
(5.64)\end{array}$ \\
\hline Threats to kill $(2+)$ & 407 & 1 & 0.25 & $\begin{array}{r}7.35 \\
(5.63) \\
\end{array}$ \\
\hline Blackmail(1) & 4,902 & 26 & 0.53 & $\begin{array}{l}12.59 \\
(6.43) \\
\end{array}$ \\
\hline Blackmail(2+) & 241 & 0 & 0.00 & $\begin{array}{l}11.10 \\
(6.48)\end{array}$ \\
\hline Kidnapping(1) & 6,096 & 31 & 0.50 & $\begin{array}{r}8.11 \\
(5.60)\end{array}$ \\
\hline Kidnapping(2+) & 216 & 1 & 0.45 & $\begin{array}{r}6.45 \\
(4.88) \\
\end{array}$ \\
\hline Arson \& threats & 453 & 5 & 1.10 & $\begin{array}{r}7.30 \\
(4.90) \\
\end{array}$ \\
\hline Arson \& blackmail & 156 & 2 & 1.28 & $\begin{array}{r}11.9 \\
(5.41)\end{array}$ \\
\hline Arson \& kidnapping & 219 & 3 & 1.37 & $\begin{array}{r}7.92 \\
(5.05) \\
\end{array}$ \\
\hline Threats \& blackmail & 103 & 0 & 0.00 & $\begin{array}{r}8.63 \\
(5.08) \\
\end{array}$ \\
\hline Threats \& kidnapping & 375 & 5 & 1.33 & $\begin{array}{r}7.76 \\
(5.48) \\
\end{array}$ \\
\hline Blackmail \& kidnapping & 343 & 4 & 1.17 & $\begin{array}{r}7.85 \\
(5.92) \\
\end{array}$ \\
\hline A \& Th \& B & 7 & 0 & 0.00 & $\begin{array}{r}7.95 \\
(6.06) \\
\end{array}$ \\
\hline A \& Th \& K & 23 & 0 & 0.00 & $\begin{array}{r}6.46 \\
(4.09) \\
\end{array}$ \\
\hline$A \& B \& K$ & 5 & 0 & 0.00 & $\begin{array}{r}5.18 \\
(3.71) \\
\end{array}$ \\
\hline Th \& B \& K & 16 & 0 & 0.00 & $\begin{array}{r}8.19 \\
(5.34) \\
\end{array}$ \\
\hline$A \& T h \& B \& K$ & 2 & 0 & 0.00 & $\begin{array}{r}5.39 \\
(4.35) \\
\end{array}$ \\
\hline Total & 67,052 & 353 & 0.52 & \\
\hline
\end{tabular}


Table 3: Percentage of serious offenders convicted of two types of serious offences who are subsequently convicted of homicide from 1979 to 2001 in England and Wales.

\begin{tabular}{|c|c|c|c|c|c|}
\hline \multicolumn{2}{|c|}{ Type of dataset } & \multirow{2}{*}{$\begin{array}{r}\begin{array}{c}\text { No. of } \\
\text { offenders }\end{array} \\
251\end{array}$} & \multirow{2}{*}{$\begin{array}{c}\text { No. of } \\
\text { subsequent } \\
\text { homicides } \\
2\end{array}$} & \multirow{2}{*}{$\begin{array}{l}\% \\
0.80 \\
\end{array}$} & \multirow{4}{*}{$\begin{array}{c}\begin{array}{c}\text { Average } \\
\text { follow-up time } \\
\text { in years } \\
\text { (SD) }\end{array} \\
\begin{array}{r}7.30 \\
(4.90)\end{array}\end{array}$} \\
\hline \multirow{3}{*}{$\begin{array}{l}\text { Arson \& } \\
\text { threats }\end{array}$} & $\mathrm{A} / \mathrm{T}$ & & & & \\
\hline & T/A & 87 & 3 & 3.45 & \\
\hline & AT & 115 & 0 & 0.00 & \\
\hline \multirow{3}{*}{$\begin{array}{l}\text { Arson \& } \\
\text { blackmail }\end{array}$} & $A / B$ & 71 & 1 & 1.41 & \multirow{3}{*}{$\begin{array}{r}11.9 \\
(5.41)\end{array}$} \\
\hline & $\mathrm{B} / \mathrm{A}$ & 41 & 1 & 2.44 & \\
\hline & $A B$ & 44 & 0 & 0.00 & \\
\hline \multirow{3}{*}{$\begin{array}{l}\text { Arson \& } \\
\text { kidnapping }\end{array}$} & $\mathrm{A} / \mathrm{K}$ & 136 & 1 & 0.74 & \multirow{3}{*}{$\begin{array}{r}7.92 \\
(5.05)\end{array}$} \\
\hline & $\mathrm{K} / \mathrm{A}$ & 37 & 2 & 5.41 & \\
\hline & $\mathrm{AK}$ & 46 & 0 & 0.00 & \\
\hline \multirow{3}{*}{$\begin{array}{l}\text { Threats \& } \\
\text { blackmail }\end{array}$} & $\mathrm{T} / \mathrm{B}$ & 20 & 0 & 0.00 & \multirow{3}{*}{$\begin{array}{r}8.63 \\
(5.08)\end{array}$} \\
\hline & $\mathrm{B} / \mathrm{T}$ & 40 & 0 & 0.00 & \\
\hline & TB & 43 & 0 & 0.00 & \\
\hline \multirow{3}{*}{$\begin{array}{l}\text { Threats \& } \\
\text { kidnapping }\end{array}$} & $\mathrm{K} / \mathrm{T}$ & 40 & 0 & 0.00 & \multirow{3}{*}{$\begin{array}{r}7.76 \\
(5.48)\end{array}$} \\
\hline & $\mathrm{T} / \mathrm{K}$ & 39 & 0 & 0.00 & \\
\hline & $\mathrm{KT}$ & 296 & 5 & 1.69 & \\
\hline \multirow{3}{*}{$\begin{array}{l}\text { Blackmail \& } \\
\text { kidnapping }\end{array}$} & $\mathrm{B} / \mathrm{K}$ & 47 & 1 & 2.13 & \multirow{3}{*}{$\begin{array}{r}7.85 \\
(5.92)\end{array}$} \\
\hline & $\mathrm{K} / \mathrm{B}$ & 11 & 0 & 0.00 & \\
\hline & BK & 285 & 3 & 1.05 & \\
\hline \multicolumn{2}{|l|}{ Total } & 1,702 & 19 & 1.12 & - \\
\hline
\end{tabular}

Note: A/T represents a target conviction of arson followed by a later conviction of threats to kill (possibly also with later arson offences), on the other hand, TIA indicates a target conviction of threats to kill with later aarson conviction. AT indicates that the target conviction was a co-conviction of both arson and threats to kill. 
Table 4: Cox proportional hazards model (adjusted for time at risk) for subsequent homicide conviction following one or more sample offences.

\begin{tabular}{|c|c|c|c|c|c|}
\hline & coef & s.e. & $\begin{array}{l}\text { Relative } \\
\text { Risk }\end{array}$ & z & $p$ \\
\hline $\begin{array}{l}\text { Log(No. previous } \\
\text { convictions) }\end{array}$ & 0.7949 & 0.0622 & 2.214 & 12.781 & $<0.001$ \\
\hline Age at conviction & -0.0493 & 0.0079 & 0.952 & -6.238 & $<0.001$ \\
\hline Gender: & - & - & - & - & - \\
\hline Female & -0.5798 & 0.2846 & 0.56 & -2.037 & 0.042 \\
\hline $\begin{array}{l}\text { First serious conviction: } \\
\text { Arson }\end{array}$ & - & - & - & - & - \\
\hline Blackmail & -0.1267 & 0.2043 & 0.881 & -0.62 & 0.540 \\
\hline Kidnapping & 0.394 & 0.189 & 1.483 & 2.084 & 0.037 \\
\hline Threats to kill & 0.4387 & 0.1699 & 1.551 & 2.582 & $<0.001$ \\
\hline Co-conviction & 0.2872 & 0.4669 & 1.333 & 0.615 & 0.540 \\
\hline $\begin{array}{l}\text { No. different types of } \\
\text { serious sample offences }\end{array}$ & 0.6015 & 0.2946 & 1.825 & 2.041 & 0.041 \\
\hline
\end{tabular}

Table 5: Relationship of specialised and non-specialised serious offending for four types of offences.

\begin{tabular}{l|r|r|r|r}
\hline \hline & Arson & Blackmail & Kidnapping & Threats to kill \\
\hline Specialised only (2+) & $\begin{array}{r}3,664 \\
(8.0 \%)\end{array}$ & $\begin{array}{r}241 \\
(4.2 \%)\end{array}$ & $\begin{array}{r}216 \\
(3.0 \%)\end{array}$ & $\begin{array}{r}407 \\
(4.1 \%)\end{array}$ \\
\hline Not specialised (2+) & 866 & 631 & 979 & 970 \\
& $(1.9 \%)$ & $(10.9 \%)$ & $(13.4 \%)$ & $(9.9 \%)$ \\
\hline Total with two or more & 4,530 & 872 & 1,195 & 1,377 \\
serious offences & $(9.9 \%)$ & $(15.1 \%)$ & $(16.4 \%)$ & $(14.0 \%)$ \\
\hline One only & 41,385 & 4,902 & 6,096 & 8,439 \\
\hline TOTAL & $(90.1 \%)$ & $(84.9 \%)$ & $(83.6 \%)$ & $(86.0 \%)$ \\
\hline \hline
\end{tabular}




\section{Footnotes}

${ }^{1}$ This procedure was possible for the offences of arson, blackmail and threats to kill, but not for kidnapping. Kidnapping was only coded as a separate offence in the Offenders Index in 1979 - previously it was included in the 'Others' category. Hence, in theory, the kidnapping dataset could include persons who were convicted of kidnapping prior to 1979; however, we believe that this would involve few persons.

${ }^{2}$ In theory, a person could, in fact, have a conviction for any of these offences prior to 1963 when the Offenders Index started. However, this could only happen with offenders aged 27 years or more in 1979. For someone to have a conviction for one of the four serious offences and then have a gap of at least 16 years before being convicted of one of these four offences again would be rare.

${ }^{3}$ The estimate of the time from conviction to release being around $30 \%$ of sentence awarded was made as follows. 1995 Prison Statistics in England and Wales (Home Office, 1996) contain an estimate that, for adult males, between $40 \%$ and $50 \%$ of sentence awarded is actually served (Table 4.14). However, this includes time spent on remand before conviction. $48 \%$ of the prison population spent time on remand, with an average of around 60 days increasing to around a year for some cases. (Chapter 2, ibid). This gave a reduction of between $10 \%$ and $15 \%$ depending on sentence awarded, giving the final result of 30\%. Data for other years are similar and 1995 figures are representative of the period under study

${ }^{4}$ The 'narrow sense' of specialisation means, for example, a conviction for arson followed by another conviction for arson. However, there is scope for similar behaviour being included in the notion of specialisation - a conviction for criminal damage may, for example, be considered as similar behaviour to arson. 